\title{
Is supplementation justified to compensate pastoral calves for milk restriction?
}

\author{
D. LAYNE COPPOCK AND SANDRO SOVANI
}

Authors are associate professor, Department of Rangeland Resources, Utah State University, Logan, Utah 84322-5230, and research veterinarian, v. Irpina 23, 58100 Grosseto, Italy. At the time of research, the authors were research scientist and research associate, respectively, at the International Livestock Center for Africa (ILCA), P.O. Box 5689, Addis Ababa, Ethiopia.

\begin{abstract}
Competition for milk between calves and pastoral herders may reduce weaning weights, retard growth, and delay puberty in cattle. Calf supplementation could over-ride such effects and improve pastoral economies. To examine these issues in semiarid Ethiopia, 266 Boran calves (Bos indicus) were used in a $2 \times 3$ plus 1 factorial design contrasting graded levels of supplemental alfalfa hay (i.e., Medicago sativa $\mathbf{L}$. with mean intakes of 0,344 , and $557 \mathrm{~g}^{\text {head }^{-1}}$ day $^{-1}$ on a DM basis) and supplemental water (i.e., with mean intakes of 0 and 3.8 liters head $\left.{ }^{-1} \mathrm{day}^{-1}\right)$. The trial was repeated for animals born in 2 consecutive years. Treatments occurred over a background of simulated traditional management in which calves had limited access to grazing and water and were allowed to suckle about two-thirds of their dams' daily milk yield. Traditionally managed controls received no supplements while other (positive) controls received no supplements but had greater access to milk. After 10 months of treatment calves were weaned and monitored. Supplementation with the high level of hay plus water markedly enhanced $(P<0.01)$ all productive features of calves at weaning compared to traditionally managed controls, and was an effective substitute for milk forgone in both years. Despite high variability in milk intake, access to supplements, and weaned body size as calves, all male cattle converged in liveweight and other productive features by 3.5 years of age, largely due to compensatory growth of traditionally managed controls. Heifers also converged in various attributes at maturity, but those which had received hay plus extra water as calves still conceived 2.6 to 4.3 months earlier $(\mathbf{P}<0.05)$ than traditionally managed controls. We concluded that supplementation with hay and water can indeed compensate a young calf for typical levels of milk restriction here. Carry-over effects, however, were insufficient to justify large investments in supplementation consid-
\end{abstract}

Research was conducted under the auspices of the Ethiopian rangelands program at ILCA. The authors thank Eshetu Zerihun and his assistants for implementing the research. Mesfin Shibre, Mr. J. Sherington, and Dr. E. W. Richardson helped with statistical analyses. The Southern Rangelands Development Unit (SORDU) of the Ethiopian Third Livestock Development Project (TLDP) gave permission to use Demballa Wachu ranch for initial phases of research. The SORDU veterinary service assisted with health management of our cattle. Assistance from CARE-Ethiopia with cattle procurement is greatly appreciated. Finally, we acknowledge the 2 anonymous reviewers who helped us improve the manuscript.

Manuscript accepted: 26 Jul. 1998.

\section{Resumen}

La competencia por leche entre becerros y los pastores de sistemas pastoriles puede reducir los pesos al destete, retardar el crecimiento y retrasar la pubertad del ganado. La suplementación a los becerros puede anular o aminorar tales efectos y mejorar las economías pastoriles. Para examinar estos problemas en la Etiopía semiárida, se utilizaron 266 becerros Boran (Bos indicus) $e$ n un diseño factorial de $2 \times 3$ mas 1 para contrastar niveles graduales de suplementación de alfalfa (Medicago sativa $\mathrm{L}$. con consumos medios de 0,344 , y $557 \mathrm{~g}$ cabeza $^{-1}$ dia $^{-1}$ en base a materia seca) y agua suplementaria (con consumos medios de 0 y 3.8 litros cabeza ${ }^{-1}$ dia $^{-1}$ ). El ensayo se repitió para animales nacidos en 2 años consecutivos. Los tratamientos se diseñaron basado en antecedentes de un manejo tradicional simulado en el cual los becerros tenían acceso limitado a apacentar y al agua y se les permitió amamantar aproximadamente dos terceras partes de la producción diaria de leche de sus madres. Los controles fueron animales que recibieron el manejo tradicional sin recibir suplemento, mientras otros animales control (positivo) no recibieron suplemento pero tuvieron un mayor acceso a la leche. Después de 10 meses de tratamiento los becerros fueron destetados y monitoreados. La suplementación con un alto nivel de heno mas agua incremento marcadamente $(\mathrm{P}<0.01)$ todas las características productivas de los becerros al momento del destete en comparación con los becerros que recibieron el manejo tradicional (control) y esta suplementación fue un substituto efectivo de la leche de la que fueron privados los animales en ambos años. A pesar de la alta variabilidad en el consumo de leche, acceso a suplementos y tamaño corporal de los becerros destetados, a los 3.5 años, todos los machos fueron similares en peso vivo y otras características productivas. Esto debido principalmente al crecimiento compensatorio de los becerros que recibieron el manejo tradicional (control). Al llegar a la madurez, las vaquillas también fueron similares en varios atributos, pero aquellas que recibieron heno mas agua extra cuando eran becerras concibieron de 2.6 a 4.3 meses antes de las manejadas tradicionalmente. Concluimos que la suplementación con heno y agua puede compensar a los becerros jóvenes las restricciones típicas de leche a las que se someten. Sin embargo, los efectos totales fueron insuficientes para justificar las grandes inversiones en suplementación considerando los altos riesgos inherentes de la producción y tradiciones de mercadeo de animales maduros. 
ering the high inherent risks of production and traditions of marketing mature animals.

Key Words: Cattle nutrition, compensatory growth, puberty, seasonal environments, watering frequency, Borana pastoralists, Ethiopia.

Traditional African pastoralists rely on milk from livestock as their dietary mainstay. In cattle production systems pastoralists may take up to $65 \%$ of total milk yield, with the remainder left for calves (Dahl and Hjort 1976, Holden et al. 1991). It has been speculated that competition between calves and people for milk is a major contributor to lower weaning weights, stunting, and delays in time to puberty for cattle (Dahl and Hjort 1976, Waters-Bayer 1988, Preston 1989). Given that reliance on milk by pastoralists is unlikely to change, it has been hypothesized that a major production intervention would be to compensate calves for nutrients lost as a result of milk restriction. This strategy could have major implications for improving animal production if carry-over effects occurred as sustained improvements in mature weights and reductions in time to puberty for heifers (Cossins and Upton 1988). Improved nutritional management for calves could be implemented using cutand-carry feeding with improved forages and perhaps additional water in semiarid, pastoral production systems.

The core objectives of this work were to experimentally test hypotheses that supplementation of nursing calves with alfalfa hay ( Medicago sativa L.) and/or water could: (1) compensate animals for moderate levels of milk restriction until weaning, and (2) elicit sustained and significant improvements in the subsequent performance of animals up to sexual maturity. A third objective was to use the experimental results to help answer the question of whether or not calf supplementation could be an economically viable means to improve the production system of Borana pastoralists in southern Ethiopia.

\section{Materials and Methods}

\section{Study Area}

Research was conducted on and near Demballa Wachu ranch, a government- managed facility on the Borana Plateau $610 \mathrm{~km}$ south of Addis Ababa near the Kenya border. A semiarid climate supports perennial savanna vegetation. Annual rainfall averages 500 to 600 $\mathrm{mm}$, with about $60 \%$ received during the long rains from April to May and $30 \%$ during the short rains from October to November. Rainy periods are separated by a cool dry season (June to September) and a warm dry season (December to March). The dominant ethnic group is the Boran, who are seminomadic and herd cattle. Forage resources are dynamic. Standing crops of herbaceous material can vary from 1.5 to 4.5 tonnes $\mathrm{DM}$ ha $^{-1}$ in dry and wet periods, respectively (Menwyelet 1990). Grazed portions of calf diets, on a DM basis, can have $17 \% \mathrm{CP}$ and $73 \%$ in vitro digestibility in wet periods, and this can decline to $<7 \% \mathrm{CP}$ and $55 \%$ digestibility in dry seasons (Unpublished data, Coppock). Calving is highly seasonal, as $60 \%$ of births occur during the long rains. This birth peak is accompanied by a flush of milk production which subsequently declines in dry periods. Cattle drink from ponds in rainy periods. In dry periods cattle drink water lifted from deep wells using human labor. Watering frequency for adult cattle can vary from daily (rainy periods) to once every 4 days (at the end of dry periods). Limitations of water and forage, therefore, can constrain animal productivity. Water restriction is permitted by the relatively cool climate and is implemented to minimize labor (Nicholson 1987).

\section{Animals, Diets, and Experimental Design}

A growth trial was repeated for 2 groups of local Boran calves (Bos indicus) born in consecutive years. Alberro (1986) describes the dual-purpose Boran breed.

Early in 1986, 147 Boran cows in the third trimester of pregnancy were purchased from local pastoralists. Calves were born during March to May, 1986, stratified by sex and birthdate, and randomly allocated among 7 treatments (i.e., $n=21$ for year 1 ). Cows were subsequently re-bred and produced 119 more calves during March to May, 1987. These calves were similarly assigned to the same 7 treatments (i.e., $n$ $=17$ for year 2). Local rainfall varied from $477 \mathrm{~mm}$ in the first year (i.e., from April, 1986, through March, 1987) to $300 \mathrm{~mm}$ in the second year (i.e., from April, 1987, through March, 1988; Unpublished data, Coppock).

Six of the 7 treatments were incorporated into a factorial design involving supplementation with graded levels of water and alfalfa hay, offered to calves over a background of grazing and restricted access to milk and water. Treatments included 2 levels of supplemental water intake (i.e., ad-libitum and zero) and 3 levels of supplemental hay intake [i.e, ad-libitum (high), 60\% of high (medium), and zero]. The high level of hay offered was set at $20 \%$ above the previous day's intake while the medium level offered was $60 \%$ of the high level. Alfalfa is not traditionally grown in these rangelands. It was selected because its feeding value is well-recognized and it offered the best possibility of eliciting improved cattle performance. Local legumes would have to substitute for alfalfa in new feeding systems for Boran calves (Coppock and Reed 1992). Alfalfa was harvested at $50 \%$ flowering, baled after sun drying, and chopped to $25-\mathrm{cm}$ lengths before feeding. Chemical content (DM basis) was $21.2 \% \mathrm{CP}, 65.6 \%$ IVDMD, and $42 \%$ NDF (Coppock and Reed 1992).

Supplements were offered nightly at 1800 hours in buckets to individual calves under confinement. The 6 factorial treatments were superimposed over a background that simulated traditional calf management from birth to weaning. As with other pastoralists, calf management by the Boran involves intensive hand-rearing, and, except for brief bouts of suckling, calves are kept from their dams to ensure sufficient milk for people. The background in our trial consisted of: (1) individually housing calves at night in small mud-and-thatch huts, (2) limiting daily milk intake for calves to around half of production by allowing calves to suckle 2 of 4 quarters from their dams for a few minutes in the morning and evening, (3) after 2 months of age, allowing calves to graze daily in a calf herd on Pennisetum mezianum Leeke range, and (4) altering watering frequency as water availability changed with season. Background watering frequency for all cows and calves in the trial varied from daily at the height of the rainy season to once every 3 to 4 days at the height of the dry season. A 
seventh treatment was not part of the factorial design and calves in this group did not receive supplements. The background for the seventh group only differed in that these calves received about 12 hours of continuous access to milk each night because they were corralled with their dams. The seventh treatment was intended to illustrate production potential in the absence of milk competition with people. It would also provide a comparative baseline to quantify whether supplementation could off-set effects of milk restriction.

Supplemental hay or water was first offered when calves began to graze, and supplementation continued until calves were weaned. The treatment period roughly occurred from July through March each year, ending at the onset of the long rains in April of 1987 and 1988. The treatment period thus covered an average of 9 months in 1986-7 (year 1) and 7 months in 1987-8 (year 2). Daily intake of supplements was expected to fluctuate according to seasonal resource dynamics and increase as calves grew. Range forage was senescent for about 5 to 7 months of the treatment periods in 1986-7 and 1987-8, respectively. Forage was green during and briefly after the short rains in October and November of both years.

Hay and water refusals were removed and measured each morning, and intake was estimated by difference. Milk intake was estimated bi-weekly for each calf using a weigh-suckle-weigh method (Coppock and Reed 1992). After suckling each cow was hand-milked and the residual yield was measured. This allowed estimation of total milk yields and percent of total yields received by calves. Background (i.e., non-supplemental) water intake was measured biweekly when all calves drank from known amounts in buckets. Daily water intake was calculated by dividing amounts consumed by watering frequency. Intake of the grazed diet was not measured because logistics in this remote area prohibited fecal collection for large numbers of nursing calves (Coppock and Reed 1992). We therefore focused on an empirical assessment of supplementation effects.

Prior to weaning liveweights and shoulder heights of each calf were measured bi-weekly. Shoulder height was measured from the base of the right front hoof to the top of the scapula.
Shoulder height was used to assess frame size and to derive a weight:height ratio as an index of body condition. After weaning, calves were no longer housed nightly in huts and managed by research staff, but were kept at nearby pastoral encampments. Research animals were maintained under traditional management until females reached puberty 3 to 4 years later. Pastoral management of immatures included corraling for about 12 hours each night and grazing by day in mixed savanna sites. Watering frequency again varied from daily (wet periods) to once every 3 to 4 days (dry periods). Travel to dry-season watering points required $20-\mathrm{km}$ roundtrips from encampments.

At the encampments liveweights and shoulder heights of males were measured monthly. Females were similarly monitored until they were 24 months old, anticipated to be the earliest age at which they could become puberal. At 24 months females were run with breeding bulls at a ratio of 20:1. Every 10 days females were weighed and blood was collected from jugular veins for analysis of plasma progesterone. Blood was centrifuged on site and plasma was stored at $-20^{\circ} \mathrm{C}$ for future analysis using the Enzyme-Linked Immuno Assay (ELISA) technique (Mukasa-Mugerwa et al. 1989) using Ovucheck test kits (Cambridge Veterinary Sciences, UK).

Onset of puberty was verified using 3 complementary methods: (1) animals were observed for successful mounts, recorded as to date and hour, (2) rectal palpations were conducted for pregnancy diagnosis (through detection of asymmetry of uterine horns and presence of enlarged embryonic vesicula) at 40 and 60 days post-mating, and (3) analysis of plasma progesterone was conducted for 4 samples collected within 10 days before and 30 days after an observed mount. Plasma progesterone levels over a threshold of $1.3 \mathrm{ng} \mathrm{ml}^{-1}$ were considered indicative of a significant rise in hormone concentrations associated with estrous and an active corpus luteum. This conservative limit was specifically tailored for our sample population (Personal communication, Mukasa-Mugerwa). The value of $1.3 \mathrm{ng}$ $\mathrm{ml}^{-1}$ represented the upper limit of 2 standard deviations above the mean basal concentrations of plasma progesterone (Unpublished data, Sovani). If the pregnancy diagnosis and proges- terone analyses were positive, the date of mating was considered to be the date of puberty. Routine rectal palpations were also conducted for all animals on a monthly basis to provide a backup in case matings were unobserved.

\section{Statistics}

Our experiment proceeded smoothly from April 1986, until June 1991. The first group of animals were successfully monitored as planned. The trial was scheduled to end by August 1991, after the second group of heifers would have all become puberal. Regional insecurity associated with an overthrow of the central government, however, required that work be abruptly terminated in mid1991. This meant we had to use a piecemeal approach for data analysis given that the first group of animals had been fully evaluated and many in the second group had not. For example, because most heifers in the second group had not been observed to reach puberty, only reproductive data from the first group of heifers were analyzed. The main analyses included factorial ANOVA to assess: (1) effects of birth year, hay level, and water level on liveweight, shoulder height, and weight:height ratio for calves at weaning as well as average daily gain (ADG) and total gain from birth to weaning, (2) effects of birth year, hay level, and water level on liveweight, shoulder height, and weight:height ratio for the first group of heifers at puberty, as well as on ADG and total gain for these heifers from weaning to puberal age, and (3) effects of the same factors on the same response variables as just mentioned in (2), but using a terminal age of 3.5 years for the second group of heifers and both groups of males, with sexes analyzed separately. Other factorial ANOVA were used to assess patterns of hay, water, and milk intake of calves during treatment periods to confirm that the trial was adequately implemented and detect interactions among dietary components and year. Factorial ANOVA were also used to examine ancillary features of the trial such as total milk yield of cows, percent of total milk yield consumed by calves, background and total water intake, etc. Simple linear regression was used to calculate ADG per head and to correlate hay intake with total water intake for calves in each 
birth year. An ANOVA was used to contrast mean production responses of animals from each of the 6 factorial treatments with those from animals in positive control groups for both years. These analyses were conducted to evaluate responses from birth to weaning and weaning to a terminal age of 3.5 years. All ANOVA employed leastsquared means (SAS 1987) and milk

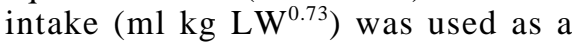
covariate in ANOVA when positive controls were omitted. Variation among means was interpreted as significant when $\mathrm{P}<0.05$. Dunnett's procedure (Day and Quinn 1989) was used to make 6 planned comparisons between the positive control group and each of the 6 factorial treatments in both years. Contrasts for linear trend were used to examine main effects of hay feeding level when higher-order interactions were absent (Winer et al. 1991).

\section{Results}

\section{Trial Implementation}

Intakes of supplements and milk by calves according to factorial treatment are illustrated in Table 1. There were some significant interactions involving year and intake of water, hay, and milk that merit brief review. It is useful to recall that year 1 had nearly $60 \%$ higher rainfall than year 2 , and this had a marked influence on most aspects of the trial. Compared to year 1 , the relative dryness of year 2 reduced the time that green forage was available for cows or calves and reduced availability of drinking water. Calves therefore tended to consume more supplements, and less milk, in year 2 than year 1 .
Averaged across water levels and years, hay DM intake averaged 344 and $557 \mathrm{~g} \mathrm{head}^{-1}$ day $^{-1}$ for the medium and high levels offered, respectively (Table 1). Hay intake was affected by year and showed an interaction with supplemental water (both at $\mathrm{P}=0.0001$ ). Averaged across the 2 levels of hay offered, calves ate 307 versus $595 \mathrm{~g}$ head $^{-1}$ day $^{-1}$ in year 1 and 2, respectively. Compared to year 1 and averaged across water levels, hay intake for animals on the medium level in year 2 increased by $103 \%$ from 227 to $462 \mathrm{~g} \mathrm{head}^{-1}$ day $^{-1}$ while hay intake for animals on the high level increased in year 2 by $87 \%$ from 387 to $727 \mathrm{~g} \mathrm{head}^{-1}$ day $^{-1}$. Calves in year 1 that received supplemental water ate $27 \%$ more hay than those which did not receive supplemental water (i.e., 271 versus $343 \mathrm{~g}^{\text {head }^{-1}}$ day $\left.^{-1}\right)$. In year 2 calves which received supplemental water ate $20 \%$ more hay than those which did not receive supplemental water (i.e., 541 versus $649 \mathrm{~g}$ head $^{-1}$ day $^{-1}$ ). Linear regression results for year 2 indicated that hay DM intake (y) in $\mathrm{g} \mathrm{head}^{-1}$ day $^{-1}$ was related to total water intake (x) in $\mathrm{ml} \mathrm{head}^{-1} \mathrm{day}^{-1}$ by the equation $\mathrm{y}=0.036 \mathrm{x}+322.8(\mathrm{P}=$ $\left.0.0062 ; r^{2}=0.11 ; d f=66\right)$. No such relationship, however, was apparent for year $1(\mathrm{P}=0.23)$.

Intake of supplemental water was $25 \%$ higher in year 2 compared to year 1 overall (Table 1). There was also a significant hay $\mathrm{x}$ water $\mathrm{x}$ year interaction $(\mathrm{P}<0.001)$ indicating that calves on the high level of hay drank relatively more supplemental water than other groups, especially in year 2. In wetter year 1 , targeted calves consumed an average of 3.2 liters head ${ }^{-1}$ day $^{-1}$ of supplemental water. This increased intake of water 2.7-fold to 5.1 liters head ${ }^{-1}$ day $^{-1}$ from a background of 1.9 liters head ${ }^{-1}$ day $^{-1}$ (not tabulated). In drier year 2, targeted calves consumed an average of 4.0 liters head $^{-1} \mathrm{day}^{-1}$ of supplemental water. This increased intake of water 3.5-fold to 5.6 liters head ${ }^{-1}$ day $^{-1}$ from a background of 1.6 liters head ${ }^{-1}$ day $^{-1}$.

There were main effects of birth year on calf age at weaning, total milk yield of cows, and daily and total milk intake for calves (all at $\mathrm{P}<0.01$ ). Weaning age for the first and second groups of calves averaged 324 and 270 days, respectively. Daily milk intake by calves varied from an average of 1.12 to 1.05 liters head $^{-1}$ day $^{-1}$ in years 1 and 2 , respectively. Daily milk intake exhibited a significant hay $\mathrm{x}$ water interaction $(\mathrm{P}=0.002)$; milk intake was higher for traditionally managed controls over both years (Table 1). Total milk intake for calves varied from 363 to 283 liters head ${ }^{-1}$. Total milk yield (i.e., intake plus offtake) averaged 1.79 to 1.67 liters cow $^{-1}$ day $^{-1}$ in years 1 and 2, respectively, or a total yield of 580 to 472 liters cow ${ }^{-1}$ lactation $^{-1}$. Calf milk intake averaged $67 \%$ of total yield with no effect of year $(\mathrm{P}=$ 0.77). For supplementation to compensate calves for milk restriction it would have to offset foregone milk volumes ranging from 189 to 217 liters head $^{-1}$ over the 2 years.

\section{Treatment Responses: Birth to Weaning}

The year $\mathrm{x}$ hay $\mathrm{x}$ water interaction $(\mathrm{P}$ $=0.0001)$ for weaning weight is shown in Figure 1; this primarily illustrates the effect of supplemental water in allowing animals to better utilize hay in both years. One source of the interaction of feeding treatment with year was annual

Table 1. Average daily intake ( $\bar{x} \pm$ SE) of supplemental hay ( head $^{-1}$ day $^{-1}$ on a DM basis), supplemental water (liters head ${ }^{-1}$ day $\left.^{-1}\right)$, and milk (liters $\mathrm{Kg}^{-}$ $L^{-0.73}$ day $^{-1}$ ) for calves in 6 factorial treatments over 2 years ${ }^{1}$.

\begin{tabular}{|c|c|c|c|c|c|c|c|c|c|c|}
\hline \multirow{3}{*}{ Year } & \multirow{3}{*}{$\begin{array}{c}\text { Supplemental } \\
\text { water? }\end{array}$} & \multicolumn{9}{|c|}{ Supplemental Hay Level } \\
\hline & & \multicolumn{3}{|c|}{ Zero } & \multicolumn{3}{|c|}{ Medium } & \multicolumn{3}{|c|}{ High } \\
\hline & & Hay & Water & Milk & Hay & Water & Milk & Hay & Water & Milk \\
\hline \multirow{3}{*}{1} & & $\begin{array}{c}\left(\mathrm{g} \mathrm{head}^{-1}\right. \\
\left.\text { day }^{-1}\right)\end{array}$ & $\begin{array}{c}\text { (liters head }^{-1} \\
\left.\text { day }^{-1}\right)\end{array}$ & $\begin{array}{c}\text { (liters kg } \\
\mathrm{LW}^{-\mathbf{0 . 7 3}} \text { day }^{-1} \text { ) }\end{array}$ & $\begin{array}{c}\left(\mathrm{g} \mathrm{head}^{-1}\right. \\
\left.\text { day }^{-1}\right)\end{array}$ & $\begin{array}{c}\text { liters head } \\
\left.\text { day }^{-1}\right)\end{array}$ & $\begin{array}{c}\left(_{\text {liters head }}{ }^{-1}\right. \\
\left.\mathrm{LW}^{-\mathbf{0 . 7 3}} \text { day }^{-1}\right)\end{array}$ & $\begin{array}{c}\left(\mathrm{g} \mathrm{head}^{-1}\right. \\
\left.\text { day }^{-1}\right)\end{array}$ & $\begin{array}{c}\text { (liters head } \\
\left.\text { day }^{-1}\right)\end{array}$ & $\begin{array}{c}\text { (liters kg } \\
\left.\mathrm{LW}^{\mathbf{- 0 . 7 3}} \text { day }^{-1}\right)\end{array}$ \\
\hline & No & 0 & 0 & $1.3 \pm 0.07$ & $207 \pm 3$ & 0 & $1.0 \pm 0.07$ & $333 \pm 5$ & 0 & $1.1 \pm 0.07$ \\
\hline & Yes & 0 & $3.1 \pm 0.02$ & $0.9 \pm 0.08$ & $245 \pm 5$ & $3.1 \pm 0.01$ & $1.1 \pm 0.08$ & $441 \pm 4$ & $3.5 \pm 0.01$ & $1.2 \pm 0.09$ \\
\hline \multirow{2}{*}{2} & No & 0 & 0 & $1.3 \pm 0.07$ & $460 \pm 4$ & 0 & $1.0 \pm 0.09$ & $621 \pm 5$ & 0 & $0.9 \pm 0.09$ \\
\hline & Yes & 0 & $3.5 \pm 0.02$ & $0.9 \pm 0.09$ & $464 \pm 3$ & $3.9 \pm 0.03$ & $0.9 \pm 0.09$ & $833 \pm 5$ & $4.7 \pm 0.03$ & $1.0 \pm 0.09$ \\
\hline
\end{tabular}

${ }^{1}$ Based on $\mathrm{n}=21$ or 17 calves per treatment in years 1 and 2, respectively. Intake of supplements was measured daily while milk intake was measured bi-weekly. A seventh treatment of calves served as a "positive" control group. Calves in this treatment received greater access to milk but no supplemental hay or water. Milk intake was not measured for the seventh treatment because the calves had continuous access to their dam's milk overnight. 


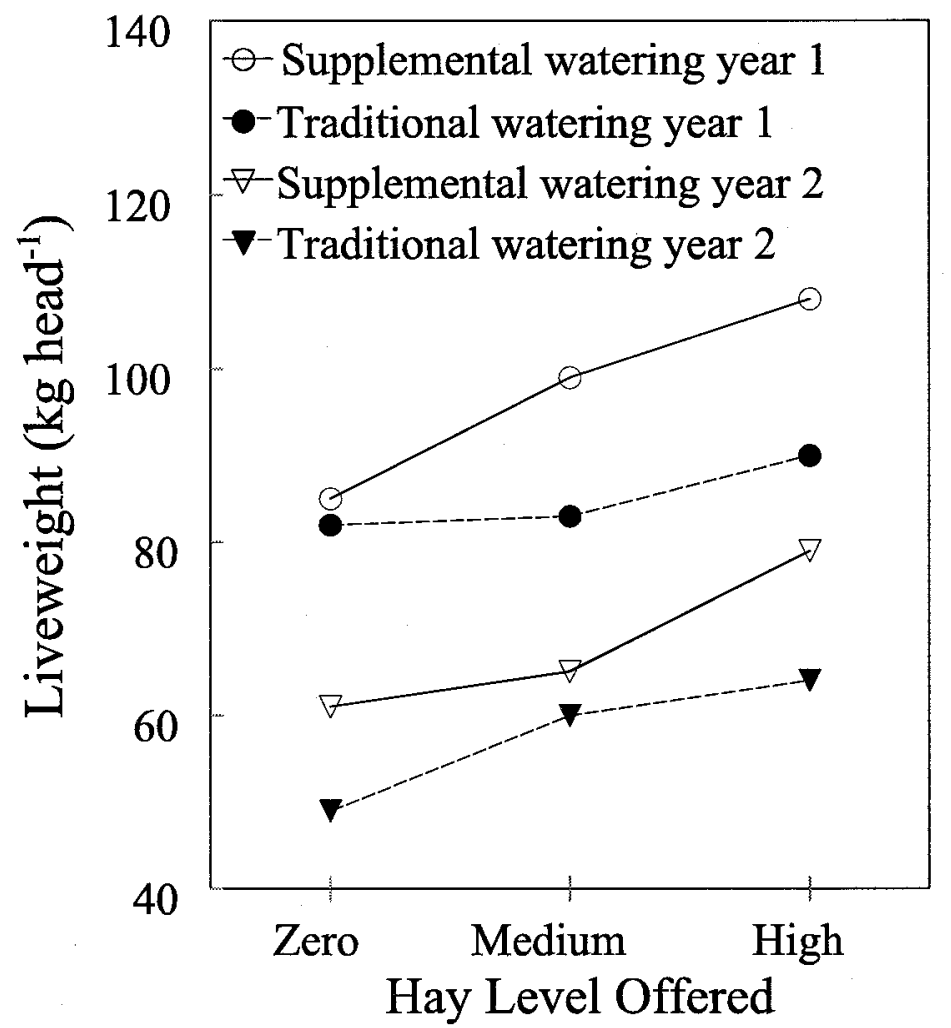

Fig. 1. Interaction of birth year, hay feeding level, and watering level on weaning weights of Boran calves (both sexes combined; $\mathbf{P}=\mathbf{0 . 0 0 0 1}$ ). The medium level of alfalfa hay intake (DM basis) averaged from 227 to $462 \mathrm{~g}^{\text {head }^{-1}} \mathrm{day}^{-1}$ in 1986-7 and 1987-8, respectively. The high level of alfalfa hay intake averaged from 387 to $727 \mathrm{~g} \mathrm{head}^{-1} \mathrm{day}^{-1}$ in 1986-7 and 1987-8, respectively.

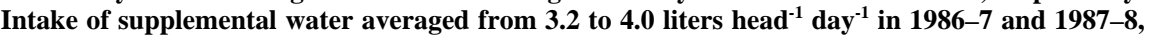
respectively.

variation in the relative impact of treatments compared to traditionally managed controls. For example, the water plus high hay treatment yielded weaning weights $31 \%$ higher than those of the controls in the first year (i.e., 108 versus $82 \mathrm{~kg} \mathrm{head}^{-1}$ ); in the second year this difference increased to $63 \%$ (i.e., 80 versus $49 \mathrm{~kg}$ head $\left.^{-1}\right)$. Other response variables exhibited qualitatively similar
For animals born in year 1, the productive performance of positive controls (i.e., those which received over-night access to milk) exceeded that for all groups except those which had received the medium or high level of hay plus extra water (Table 3 ). For animals born in year 2, the performance of positive controls exceeded that for all groups except the one which received the high level of hay plus water. These results are interpreted to indicate that supplementation with hay and water indeed helped calves fully compensate for milk restriction. In the first year $116 \mathrm{~kg}$ of hay plus 924 liters of water helped offset 217 liters of milk foregone per calf. In the second year $175 \mathrm{~kg}$ of hay plus 987 liters of water helped offset 189 liters of milk foregone per calf.

\section{Treatment Responses: Weaning to Maturity \\ Males}

Overall, main effects of birth year had the most pervasive effects on growth features for males from weaning to 3.5 years of age (Table 4). Compared to males born in the second year, those born in the first year had growth rates that were $14 \%$ higher, with an advantage in total gain of $8 \%$. At 3.5 years of age males born in the first year were $20 \%$ larger in weight and 9\% taller at the shoulder compared to those born in the second year.

Main effects of hay or water supplementation were not significant for liveweights of males at 3.5 years of age $(\mathrm{P}>0.18)$. There was an interaction, however, of water $\mathrm{x}$ hay for liveweights of males at 3.5 years $(\mathrm{P}=0.04)$. We interpreted this pattern to suggest that ani-

Table 2. Interaction of birth year with level of hay and water supplementation on calf growth features $(\overline{\mathbf{x}} \pm$ SE) from birth to weaning in 6 factorial treatments.

\begin{tabular}{|c|c|c|c|c|c|c|c|c|c|}
\hline \multicolumn{2}{|c|}{ Supplementation Group } & \multicolumn{8}{|c|}{ Growth Feature } \\
\hline \multirow[b]{2}{*}{ Water level } & \multirow[b]{2}{*}{ Hay Level } & \multicolumn{2}{|c|}{ Average Daily Gain } & \multicolumn{2}{|c|}{ Total Gain } & \multicolumn{2}{|c|}{ Shoulder Height } & \multicolumn{2}{|c|}{ Weight:Shoulder Height } \\
\hline & & $1986-7$ & $1987-8$ & $1986-7$ & $1987-8$ & $1986-7$ & $1987-8$ & $1986-7$ & $1987-8$ \\
\hline & & \multicolumn{2}{|c|}{$\left(\mathrm{g} \mathrm{head}^{-1}\right.$ day $\left.^{-1}\right)$} & \multicolumn{2}{|c|}{$\left(\mathrm{kg} \mathrm{head}^{-1}\right)$} & \multicolumn{2}{|c|}{$\left.(\mathrm{cm} \mathrm{head})^{-1}\right)^{1}$} & \multicolumn{2}{|c|}{$\left[(\mathrm{kg}: \mathrm{cm}) \mathrm{head}^{-1}\right]^{1}$} \\
\hline No & Zero & $193 \pm 9.6$ & $93 \pm 10.4$ & $62 \pm 3.7$ & $28 \pm 4.0$ & $93 \pm 1.1$ & $87 \pm 1.2$ & $0.88 \pm 0.03$ & $0.56 \pm 0.03$ \\
\hline No & Medium & $199 \pm 10.5$ & $140 \pm 13.8$ & $64 \pm 4.0$ & $39 \pm 5.3$ & $93 \pm 1.2$ & $88 \pm 1.6$ & $0.89 \pm 0.03$ & $0.68 \pm 0.04$ \\
\hline No & High & $217 \pm 10.7$ & $158 \pm 13.8$ & $70 \pm 4.1$ & $43 \pm 5.3$ & $93 \pm 1.2$ & $88 \pm 1.6$ & $0.97 \pm 0.03$ & $0.71 \pm 0.04$ \\
\hline Yes & Zero & $209 \pm 11.5$ & $140 \pm 12.9$ & $66 \pm 4.4$ & $38 \pm 4.9$ & $92 \pm 1.3$ & $89 \pm 1.5$ & $0.93 \pm 0.04$ & $0.67 \pm 0.04$ \\
\hline Yes & Medium & $261 \pm 10.9$ & $168 \pm 12.1$ & $81 \pm 4.2$ & $43 \pm 4.7$ & $95 \pm 1.2$ & $89 \pm 1.4$ & $1.00 \pm 0.03$ & $0.72 \pm 0.04$ \\
\hline Yes & High & $266 \pm 11.3$ & $222 \pm 11.8$ & $88 \pm 4.3$ & $57 \pm 4.5$ & $97 \pm 1.3$ & $92 \pm 1.3$ & $1.10 \pm 0.03$ & $0.86 \pm 0.04$ \\
\hline \multicolumn{10}{|c|}{ F-test probability } \\
\hline \multicolumn{2}{|c|}{ for 3-way interaction ${ }^{2}$} & \multicolumn{2}{|c|}{$* * *$} & \multicolumn{2}{|c|}{$* *$} & \multicolumn{2}{|c|}{$* *$} & \multicolumn{2}{|c|}{$* *$} \\
\hline
\end{tabular}

**,***Significant at the 0.01 and 0.0001 levels respectively.

${ }^{1}$ Measurements taken at weaning.

${ }^{2}$ Where $\mathrm{n}=38$ calves per treatment over 2 years, with 224 error degrees of freedom in each ANOVA. 
Table 3. Growth features $(\overline{\mathbf{x}} \pm \mathrm{SE})$ from birth to weaning for cavles in "positive” control groups having overnight access to their dam's milk ${ }^{1}$.

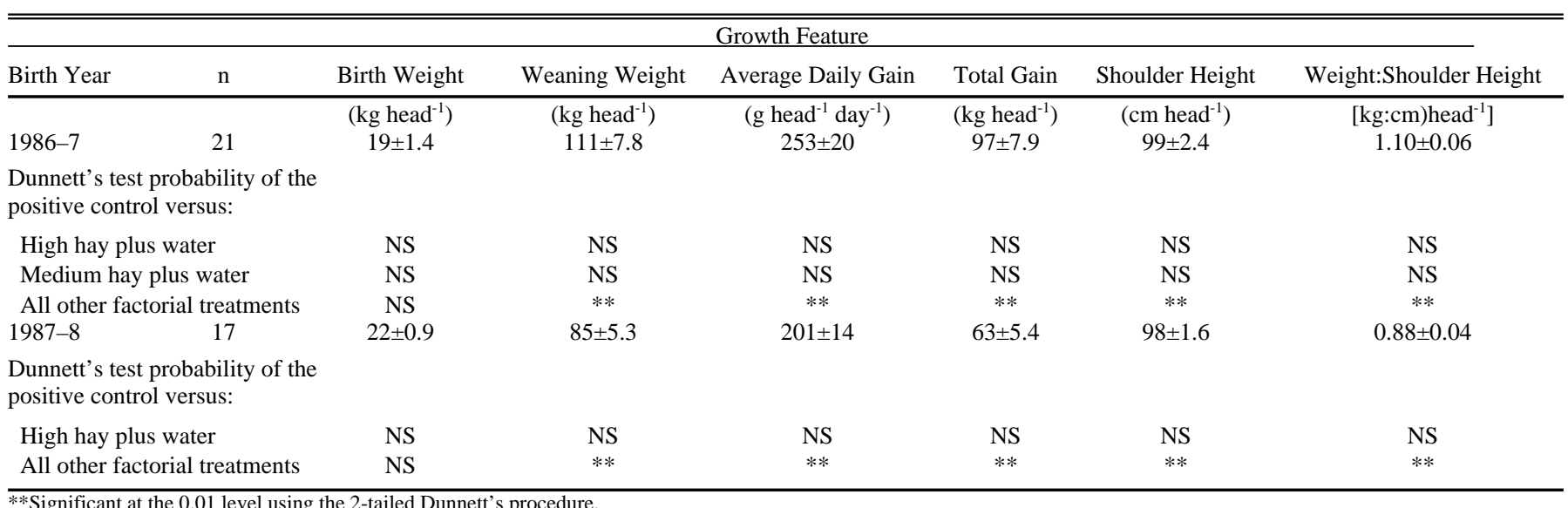

**Significant at the 0.01 level using the 2-tailed Dunnett's procedure.

${ }^{1}$ To compare means with those of respective factorial treatments also see Table 1.

${ }^{2}$ Where Dunnett's procedure was used for pre-planned comparisons between the positive control and the response from 6 factorial treatments in each year. The high hay plus water

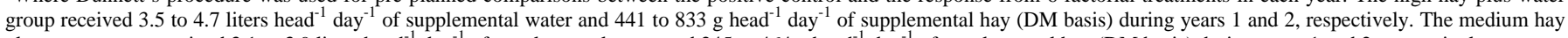
plus water group received 3.1 to 3.9 liters head ${ }^{-1}$ day $^{-1}$ of supplemental water and 245 to $464 \mathrm{~g}^{-1} \mathrm{~d}^{-1}$ day $^{-1}$ of supplemental hay (DM basis) during years 1 and 2 , respectively.

mals which had received supplemental hay and supplemental water as calves achieved higher liveweights at 3.5 years of age compared to those which had only received supplemental hay (Fig. 2). Another notable result was the trend for traditionally reared controls to have similar mean liveweights at 3.5 years of age compared to animals in the high hay plus water treatment; both of these groups had mean liveweights at 3.5 years of age that tended to exceed those found for animals in the other 4 treatments.

Averaged over both birth years, the maximum range among treatments in terms of weaning weights for males was $28 \mathrm{~kg}$ head $^{-1}$ [i.e., $66 \mathrm{~kg} \mathrm{head}^{-1}$ (controls) versus $94 \mathrm{~kg} \mathrm{head}^{-1}$ (water plus the high level of hay), a relative increase of $42 \%$ ]. By 3.5 years of age, however, males from the same 2 treatments, averaged over both years, exhibited no sig-

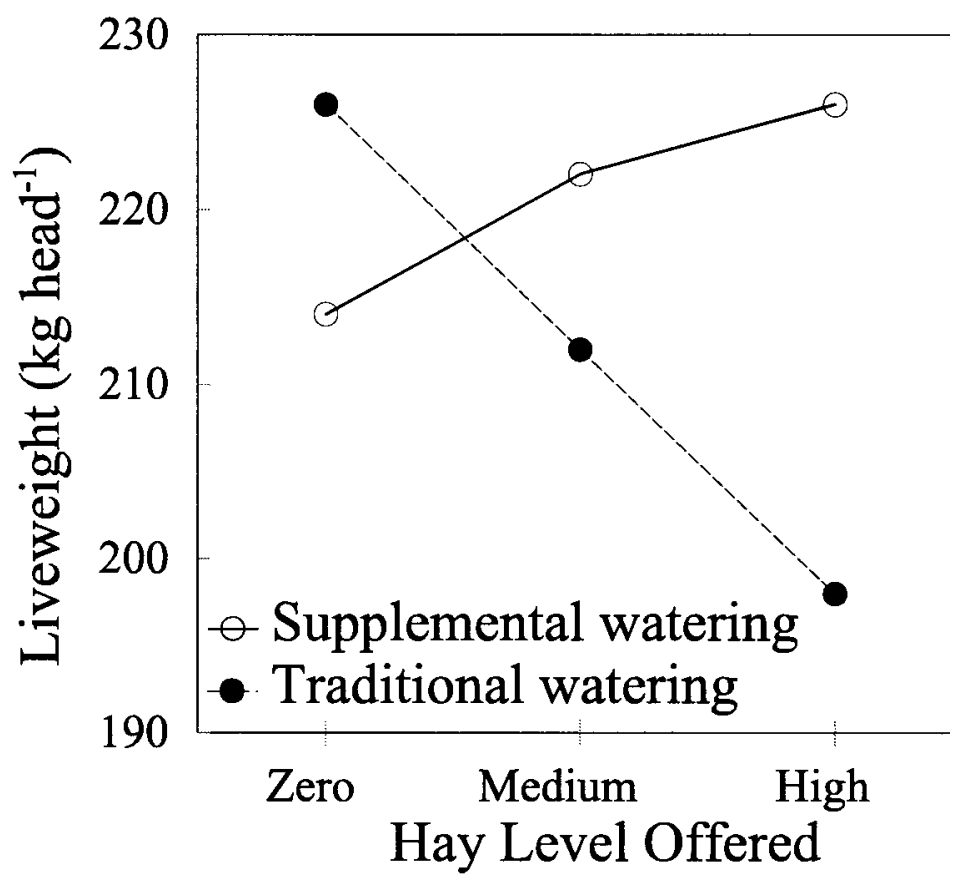

Fig. 2. Interaction of hay feeding level and watering level on liveweight of male Boran cattle at 3.5 years of age $(P=0.04)$. Animals were born over 2 consecutive years. The medium level of alfalfa hay intake (DM basis) averaged $345 \mathrm{~g} \mathrm{head}^{-1}$ day $^{-1}$ over 2 birth years while the high level of alfalfa hay intake averaged $557 \mathrm{~g} \mathrm{head}^{-1} \mathrm{day}^{-1}$. Intake of supplemental water averaged 3.6 liters head $^{-1}$ day $^{1}$ over the 2 birth years.

nificant differences in liveweight (i.e., 225 versus $226 \mathrm{~kg} \mathrm{head}^{-1}$, Fig. 2). Convergence in liveweight was reflected in the main effects of hay level on growth after weaning. Growth rates and total gain were inversely related to the amount of hay animals had consumed as calves (Table 5).

\section{Females}

The total number of heifers born in the first year was 67 across 7 treatments. Fifty four (81\%) had become pregnant before the trial ended. Forty-two percent of heifers conceived at their first behavioral estrous. In $48 \%$ of the first behavioral estrouses, however, animals were physiologically non-puberal according to analysis of their plasma progesterone levels, which were $<1.3 \mathrm{ng} \mathrm{ml}^{-1}$. These animals tended to be younger and lighter in liveweight than those which exhibited sexual behavior that coincided with plasma progesterone concentrations $>1.3 \mathrm{ng} \mathrm{ml}^{-1}$ (Unpublished data, Sovani). Mating activity was a function of nutritional plane and was thus highly seasonal. Ninety-six percent of conceptions occurred during rainy or post-rainy periods. These were divided between the short and long rains in a bimodal pattern. Forty-two percent of all conceptions occurred during or just after the short rains in November and December, while 54\% occurred during or just after the long rains in March through June.

Heifers first began to get pregnant during the short rains (October to November) of 1989 , when some were 
Table 4. Main effects of birth year on growth features of male Boran cattle from weaning to 3.5 years of age as averaged across 6 factorial treatments

\begin{tabular}{|c|c|c|c|}
\hline \multirow[b]{2}{*}{ Growth Feature } & \multicolumn{2}{|c|}{ Birth Year $^{1}$} & \multirow[b]{2}{*}{$F$-Test Probability } \\
\hline & $1986-7$ & $1987-8$ & \\
\hline$\overline{\text { Average Daily Gain }\left(\mathrm{g} \mathrm{head}^{-1} \text { day }^{-1}\right)}$ & 151 & 132 & $* *$ \\
\hline Total Gain $\left(\mathrm{kg} \mathrm{head}^{-1}\right)$ & 144 & 133 & $*$ \\
\hline Weight at 3.5 years $\left(\mathrm{kg} \mathrm{head}^{-1}\right)$ & 236 & 196 & $* * *$ \\
\hline Shoulder Height at 3.5 years $\left(\mathrm{cm} \mathrm{head}^{-1}\right)$ & 124 & 114 & $* * *$ \\
\hline Weight:Shoulder Height $\left[(\mathrm{kg}: \mathrm{cm}) \mathrm{head}^{-1}\right)$ & 1.90 & 1.72 & $* * *$ \\
\hline
\end{tabular}

$*, * *, * * *$ Significant at the $0.05,0.01$, and 0.0001 levels respectively.

${ }^{1}$ Where $\mathrm{n}=63$ males born in $1986-7$ and $\mathrm{n}=51$ born in $1987-8$, with 98 error degrees of freedom in the ANOVAs. The milk intake covariate was not significant for any case $(\mathrm{P}>0.10)$.

40 months old. Following a period of no sexual activity during the subsequent warm dry season, the next (and last) wave of pregnancies for the first group of heifers occurred during the long rains (April to May) of 1990, when the remaining animals averaged 48 months of age. The overall mean age $( \pm$ SE) at conception was thus $43.4 \pm 1.5$ months (or 3.6 years). The mean liveweight $( \pm$ SE) at conception was $217 \pm 7.1 \mathrm{~kg}$ head $^{-1}$, roughly $96 \%$ of the mature weight for females (i.e., $225 \mathrm{~kg} \mathrm{head}{ }^{-1}$; Alberro, 1986).

It was expected that heifers which had been born in the second year would begin to get pregnant starting during the short rains (October-November) of 1990. These rains, however, were sparse. Animals remained on a low plane of nutrition and few conceptions were recorded (Unpublished data, Sovani). The main wave of pregnancies for the second cohort was thus expected to occur in April to May of 1991, but this was when security collapsed and the trial had to be terminated.

Results from ANOVA which analyzed responses from weaning to puberty for females which had been born in the first year and conceived are shown in Table 6 . These animals had exhibited the same interaction response to hay and water treatment in terms of weaning weight as previously reported; the group which received water plus the high level of hay exceeded the controls by $59 \%$ (i.e., 127 versus $80 \mathrm{~kg} \mathrm{head}^{-1}$ ). At puberty, however, these weight differences had largely disappeared. Groups also tended to be similar in terms of shoulder height and weight:height ratio at puberty.

That weight at puberty converged among treatments was not due to compensatory growth per se as observed for the males. In contrast to the males, which were analyzed at a common chronological age, time to puberty varied for females due to different factor levels and this complicated interpretation of results (Table 6). Heifers that had received extra water as calves became puberal 2.7 months earlier on average than those under traditional watering (i.e., 42.5 versus 45.2 months of age, respectively). Heifers which received the high level of hay became puberal 2.6 and 4.3 months earlier than those which received the medium and zero levels of hay, respectively (i.e., means of 41.6, 44.2 , and 45.9 months).

Because of treatment variation in puberal age, groups differed in total gain from weaning to puberty, but did not differ in terms of ADG. Animals thus had to attain a similar target weight to become puberal, and this took different lengths of time depending on treatment. Total gain needed to achieve puberty after weaning varied in relation to

Table 5. Main effects of hay feeding level on growth of male Boran cattle from weaning to 3.5 years of age as averaged for animals across 6 factorial treatments born in 2 successive years. ${ }^{1}$

\begin{tabular}{lccccc}
\hline \hline & \multicolumn{2}{c}{ Hay Feeding Level } & \multicolumn{2}{c}{ F-Test Probability } \\
\cline { 2 - 5 } Growth Feature & Zero & Medium & High & ANOVA & Linear Trend $^{3}$ \\
\hline Average Daily Gain $\left(\mathrm{g} \mathrm{head}^{-1}\right.$ day $\left.^{-1}\right)$ & 153 & 142 & 129 & $*$ & $*$ \\
Total Gain $\left(\mathrm{kg} \mathrm{head}^{-1}\right)$ & 151 & 139 & 127 & $*$ & $*$
\end{tabular}

*Significant at the 0.05 level.

${ }^{1}$ Where each tabulated entry is the mean of $\mathrm{n}=38$ animals. Each ANOVA was based on 98 error degrees of freedom. The milk intake covariate was not significant for either case $(\mathrm{P}>0.10)$.

${ }^{2}$ Where the medium level consumed was 227 and $462 \mathrm{~g} \mathrm{head}^{-1}$ day ${ }^{-1}$ and the high level was 387 and $727 \mathrm{~g} \mathrm{head}^{-1} \mathrm{day}^{-1}$, in the first and second years, rspectively, on a DM basis.

${ }^{3}$ Linear contrast. whether animals received hay or water as calves (Table 6). Animals which did not receive extra water had to gain 128 $\mathrm{kg} \mathrm{head}{ }^{-1}, 16 \%$ more than those which had not received extra water (i.e., 110 $\left.\mathrm{kg} \mathrm{head}{ }^{-1}\right)$. Puberty among animals which did not receive extra water was achieved over a period of time which was 6\% longer than those which received extra water. Animals which did not receive hay had to gain $126 \mathrm{~kg}$ head $^{-1}$ after weaning to become puberal. This exceeded the gain needed by animals which received the high level of hay by $15 \%$ (i.e., $109 \mathrm{~kg} \mathrm{head}^{-1}$ ). Animals which did not receive hay, however, took $10 \%$ longer to achieve puberty.

Despite that an analysis of puberal features could not be conducted for females from the second cohort, data collected from weaning to termination of the trial allowed another factorial analysis of growth patterns from weaning to a common minimum age of 3.5 years for these animals $(n=8$ to 9 per treatment). Patterns again demonstrated convergence among treatments in liveweight, shoulder height, and weight:height ratios (all at $\mathrm{P}>0.05$; not illustrated). This occurred even though hay and water treatments resulted in greater impacts on animals relative to respective controls in the second year compared to the first (Fig. 1).

\section{Contrasts of Factorial Treatments} with Positive Controls at Maturity

An ANOVA was conducted across all 7 treatments to analyze effects of birth year and treatment on total liveweight gain and ADG from birth to 3.5 years of age, and on liveweight, shoulder height, and weight:height ratio at 3.5 years of age. Birth year was significant $(\mathrm{P}<0.005)$ for all response variables. Considering the period from birth to 3.5 years of age, animals born in wetter year 1 had $25 \%$ higher mean $( \pm$ SE) total liveweight gains (i.e., $204 \pm 3.6$ versus $163 \pm 3.3 \mathrm{~kg} \mathrm{head}^{-1}$ ) and $26 \%$ higher mean $\mathrm{ADG}$ (i.e., $157 \pm 3$ versus $125 \pm 3$ $\left.\mathrm{g} \mathrm{head}^{-1} \mathrm{day}^{-1}\right)$. At 3.5 years of age animals born in wetter year 1 had a $21 \%$ higher mean liveweight (i.e., $223 \pm 3.7$ versus $\left.185 \pm 3.4 \mathrm{~kg} \mathrm{head}^{-1}\right), 10 \%$ greater mean shoulder height (i.e., $124 \pm 1$ versus $\left.114 \pm 1 \mathrm{~cm} \mathrm{head}^{-1}\right)$, and a $12 \%$ greater weight:height ratio (i.e., $1.80 \pm$ 0.02 versus $\left.1.62 \pm 0.02 \mathrm{~kg}: \mathrm{cm} \mathrm{head}^{-1}\right)$. In contrast, however, there were no sig- 
Table 6. Growth features from weaning to puberty, and time to puberty, for Boran heifers born in 1986 as influenced by supplementation in 6 factorial treatments.

\begin{tabular}{|c|c|c|c|c|c|c|c|c|c|}
\hline \multicolumn{2}{|c|}{ Supplementation Group } & \multicolumn{8}{|c|}{ Feature } \\
\hline Water Level & Hay Level & $\begin{array}{l}\text { Weaning } \\
\text { Weight }\end{array}$ & $\begin{array}{l}\text { Puberal } \\
\text { Weight }\end{array}$ & Total Gain & $\begin{array}{l}\text { Average Daily } \\
\text { Gain }\end{array}$ & $\begin{array}{l}\text { Shoulder } \\
\text { height }^{3}\end{array}$ & Weight:Height ${ }^{3}$ & $\begin{array}{l}\text { Time:Weaning } \\
\text { to Puberty }\end{array}$ & Age at Puberty \\
\hline & & $\left(\mathrm{kg} \mathrm{head}^{-1}\right)$ & $\left(\mathrm{kg} \mathrm{head}^{-1}\right)$ & $\left(\mathrm{kg} \mathrm{head}^{-1}\right)^{2}$ & $\left(\mathrm{~g} \mathrm{head}^{-1} \text { day }^{-1}\right)^{2}$ & $\left(\mathrm{~cm}\right.$ head $\left.^{-1}\right)$ & $\left.[\mathrm{kg}: \mathrm{cm}) \mathrm{head}^{-1}\right]$ & $\left(\right.$ days head $\left.^{-1}\right)$ & (months head $^{-1}$ ) \\
\hline No & Zero & $80 \pm 6.0$ & $213 \pm 7.4$ & $133 \pm 7.2$ & $119 \pm 7.6$ & $123 \pm 2.1$ & $1.7 \pm 0.05$ & $1,129 \pm 53.0$ & $48.1 \pm 1.61$ \\
\hline No & Medium & $84 \pm 5.9$ & $211 \pm 7.2$ & $127 \pm 7.0$ & $129 \pm 7.4$ & $120 \pm 2.0$ & $1.7 \pm 0.05$ & $1.009 \pm 52.1$ & $43.9 \pm 1.62$ \\
\hline No & High & $88 \pm 4.9$ & $212 \pm 6.0$ & $124 \pm 5.9$ & $124 \pm 6.1$ & $119 \pm 1.7$ & $1.8 \pm 0.04$ & $993 \pm 43.3$ & $43.7 \pm 1.31$ \\
\hline Yes & Zero & $91 \pm 6.3$ & $210 \pm 7.7$ & $119 \pm 7.5$ & $125 \pm 7.9$ & $122 \pm 2.2$ & $1.7 \pm 0.05$ & $973 \pm 55.7$ & $43.7 \pm 1.73$ \\
\hline Yes & Medium & $112 \pm 5.6$ & $230 \pm 6.9$ & $118 \pm 6.7$ & $121 \pm 7.0$ & $124 \pm 1.9$ & $1.8 \pm 0.05$ & $974 \pm 49.4$ & $44.5 \pm 1.54$ \\
\hline Yes & High & $127 \pm 5.9$ & $220 \pm 7.3$ & $93 \pm 7.1$ & $108 \pm 7.5$ & $128 \pm 2.1$ & $1.7 \pm 0.05$ & $872 \pm 52.4$ & $39.5 \pm 1.62$ \\
\hline \multicolumn{10}{|c|}{ F-test probability: } \\
\hline \multicolumn{2}{|c|}{ Hay } & $* *$ & NS & $*$ & NS & NS & NS & NS & $*$ \\
\hline \multicolumn{2}{|c|}{ Water } & $* * *$ & NS & $* *$ & NS & $*$ & NS & $* *$ & $*$ \\
\hline \multicolumn{2}{|c|}{ Hay x Water } & $*$ & NS & NS & NS & NS & NS & NS & NS \\
\hline \multicolumn{2}{|c|}{ Linear Trend (Hay) } & - & - & - & - & - & - & - & NS \\
\hline
\end{tabular}

$* * * * * * *$ Significant at the $0.05,0.01$, and 0.0001 levels respectively.

${ }^{1}$ Where $\mathrm{n}=8$ to 9 animals per treatment. Entries are $\overline{\mathrm{x}} \pm$ SE. ANOVAs were based on 45 error degrees of freedom. See text for treatment details. The milk intake covariate was not significant in any case $(\mathrm{P}>0.13)$

${ }^{2}$ From weaning to puberty.

${ }^{3}$ Measurements taken at puberty.

nificant effects of treatment on mean total liveweight gain $(\mathrm{P}=0.48$; range $174 \pm 5.9$ to $\left.199 \pm 10.7 \mathrm{~kg} \mathrm{head}^{-1}\right)$, mean ADG $(\mathrm{P}=0.35$; range $134 \pm 4$ to $151 \pm$ $\left.8 \mathrm{~g} \mathrm{head}^{-1} \mathrm{day}^{-1}\right)$, or attributes at 3.5 years including mean liveweight $(\mathrm{P}=$ 0.14 ; range $195 \pm 6.0$ to $221 \pm 10.9 \mathrm{~kg}$ head $\left.^{-1}\right)$ and mean weight:height ratio ( $\mathrm{P}$ $=0.55$; range: $1.65 \pm 0.04$ to $1.75 \pm 0.07$ $\left.\mathrm{kg}: \mathrm{cm} \mathrm{head}^{-1}\right)$. The only persistent effect of treatment was on shoulder height, which was significantly highest in the positive control group $(\mathrm{P}=0.005)$. Averaged over both years, animals which received over-night access to milk as calves had a mean shoulder height of $126 \pm 2.4 \mathrm{~cm} \mathrm{head}^{-1}$. This exceeded means for the 6 factorial treatments by an average of $7 \%$. The range of mean shoulder heights for the factorial treatments was $116 \pm 1.4$ to $121 \pm 1.2$ $\mathrm{cm} \mathrm{head}{ }^{-1}$. Overall, we interpret these results to indicate that effects of birth year on cattle growth were much more persistent compared to those from treatments. This illustrates the powerful role of environment on cattle productivity in this system.

\section{Discussion}

Cossins and Upton (1988) used analytical modeling to evaluate potential economic impacts of improved calf management in the Borana pastoral system. They estimated that if supplemental forage could fully compensate calves for milk taken by people, it could result in a $34 \%$ gross increase in the cash value of the lifetime output per cow. It was assumed that major impacts of supplementation would include a doubling of weaning weight from 47 to $94 \mathrm{~kg} \mathrm{head}^{-1}$ and a reduction in time to puberty for heifers from 4 to 3 years. This analysis supported the theory that lifetime performance of cattle in pastoral systems is significantly limited by competition between cattle and people for milk (Dahl and Hjort 1976, Pratt and Gwynne 1977, Wagenaar et al. 1986, Waters-Bayer 1988).

We interpret our results, however, to basically refute the proposition that enhancing calf growth via supplementation is an appropriate means to transform this particular pastoral economy. This perspective is based on a synthesis that includes empirical results from this trial, an improved understanding of pastoral production goals, and consideration of how risk and uncertainty affect production decisions. These are all considered further below.

\section{Short-Term Effects: Birth to Weaning}

Our trial results supported the hypothesis that supplementation could compensate calves in terms of weaning weight for a moderate loss of milk, but it is notable that extra water was required in addition to high-quality forage to achieve this effect. Traditional watering practices thus appear to limit dry matter intake for such calves, as noted in general for pastoral livestock in Africa by
King (1983). Research intended to enhance livestock performance in Africa often has a sole focus on forage resources. Our findings indicate that benefits from improved forages would not be realized in a dry region such as this if watering constraints were ignored. Including water supplementation in our trial was therefore extremely useful.

Given our experimental results, an important question is whether calf supplementation should be promoted here or in similar systems in attempts to markedly improve weaning weights. This could be a valid point of intervention if higher weaning weights were an important production goal and offered an economic advantage to the producers. We have eventually learned, however, that neither of these conditions are generalizable to the Borana pastoral system. The critical point is that the traditional production rationale in the Borana system is not the same as that of a western cow-calf operator (Coppock 1994). In the Borana system overhead costs of production are relatively low, immature stock are commonly retained by producers to build-up herds, and mature cattle over 6 years years of age are the preferred animal for most households to sell. In contrast to selling mature stock, selling immatures is more common among poorer households who are forced to sell immatures because they have small and less-diverse inventories of animals and a chronic need to frequently buy cereal grains or other non- 
pastoral foods. Selling a mature male not only provides money for a household to buy various commodities, but also allows the seller to use the "change" to buy a couple replacement calves. The sale of a mature male thus simultaneously contributes to procurement of basic necessities as well as traditional values of herd building.

If we assumed higher weaning weights were an important production and marketing goal, could it be profitable to supplement calves? Assuming input costs of US \$0.15 per kg DM of legume hay and US \$0.03 per 10 liters of water based on labor profiles and other criteria (Mulugeta 1990), and considering calf performance in the high hay and water treatment over both years, $28 \mathrm{~kg}$ of extra weight was produced per calf as a result of $146 \mathrm{~kg}$ of hay (valued at US \$2.86) and 956 liters of water (valued at US $\$ 21.90)$. The selling price for fattened calves is US $\$ 1.00$ per kg liveweight (Unpublished data, Coppock). A net return of US \$3.24 per calf does not appear very profitable, and importantly, the costs estimated by Mulugeta (1990) did not incorporate the substantial risks and problems of acquiring sufficient quantities of supplements. The true costs of supplementation were probably underestimated, further reducing profit.

We speculate that in contrast to improving weaning weights, supplementation to mitigate calf mortality under severe milk-restriction regimes is a more relevant production objective. This would be especially important to poorer households which have lower ratios of milking cows per person compared to middle-income or wealthier households. The poor tend to deprive their calves of milk to a critical extent in order to provide more milk for family members, especially children (Holden et al. 1991, Coppock 1994). Although we do not have empirical data on the amount of supplemental forage or water needed to mitigate calf mortality under extreme cases of milk deprivation, we expect that the benefit/cost ratio would be more favorable compared to using supplementation to stimulate gain. For example, if a female calf can make it to 2 years of age in the Borana system, the likelihood of subsequent survival, and hence benefit of a lifetime of productive output, dramatically increases (Coppock 1994).

\section{Long-Term Effects \\ Growth Dynamics}

Our results falsified the hypothesis that substantial increases in early growth rates and weaning weights would result in sustained increases in liveweight or frame features for these cattle. Regardless of what level of milk, hay, or water animals received as calves, and despite relative differences in weaning weights that exceeded $60 \%$ among treatments in some cases, the animals were remarkably similar by 3.5 years of age. Convergence was typically due to compensatory growth of traditionally managed animals. This is consistent with findings elsewhere which indicate that cattle can overcome early nutritional deprivation as calves (Laster et al. 1976, Richardson et al. 1978, Tawonezvi 1989). These authors found that differences in weaning weights of calves due to variable consumption of milk and/or solid foods only persisted from 1.5 to 11 months. This is not to say, however, that permanent stunting from a higher degree of milk restriction could not occur in some cases. Milk provides important bypass nutrients, and if these are severely restricted permanent stunting in cattle can result (Preston 1989).

\section{Time to Puberty}

The marked seasonality of conception observed in this study is common in pastoral Africa (de Leeuw and Wilson 1987). That Boran heifers conceived at $96 \%$ of mature weight is higher than figures reported elsewhere for Bos indicus (Macfarlane and Worrall 1970, Wilson 1987 ) or B. taurus (Dobson and Kamonpatana 1986). This suggests that Boran cows achieve physiological and physical maturity at roughly the same time (Fitzhugh 1976). The nonpuberal estruses and prepuberal rises in plasma progesterone levels observed here have been reported elsewhere (Nelsen et al. 1985, Rutter and Randel 1986), and justified use of several puberty detection methods. Bulls were also an important factor underlying seasonal patterns of conception. Bulls typically showed no sexual behavior until they had recovered body condition during wet seasons (Unpublished data, Sovani).

Our results are interpreted to suggest that early supplementation can result in a persistent reduction on time to puberty for heifers, despite convergence among treatments in liveweight and weight:height ratios. We speculate that supplementation resulted in subtle improvements in body condition, undetected by our monitoring system, that predisposed some animals to cycle one rainy season earlier during their puberal year (Mukasa-Mugerwa 1989). Reductions in time to puberty ranged from 2.6 to 4.3 months compared to traditionally managed animals, less than half of the advantage assumed in analyses by Cossins and Upton (1988).

While a reduction in time to puberty of 2 to 4 months would be very significant in western production systems where beef heifers become puberal at 12 to 15 months of age, it is important to once again view the benefits, costs, and risks of intervening in an African context where the typical heifer is sexually mature at 36 to 48 months of age and is reared in a much more challenging environment. One risk to a pastoral producer is the likelihood that hard-won gains in animal productivity due to supplementation investment could be lost in the future due to uncontrollable events. Such events include disease outbreaks, predation, and thievery; even our trial had to be terminated by 1991 because of insecurity. Even if these events could be mitigated, the problem of variable rainfall may be the most insidious. For example, 1 simple way to lose a hardwon, 2 to 4 month advantage in time to puberty is to merely have the first rainy season fail in a heifer's puberal year. As observed in our trial, failure of one rainy season could adversely affect nutrition of heifers and bulls and delay conception until the next favorable rainy period 6 months (or more) later. Another aspect is the often calamitous impact of drought. Herd dynamics in southern Ethiopia indicate that up to $50 \%$ of the cows may die every 5 to 8 years, largely due to interactions among stocking rate, rainfall fluctuation, and bottlenecks in regional marketing systems (Coppock 1994). Such a situation clearly mitigates against substantive investments to improve animal productivity over the long term. Such risk perspectives were not incorporated into the deterministic analyses of Cossins and Upton (1988).

\section{Conclusions}

Our empirical results indicated that nutritional supplementation could help Boran cattle compensate for moderate 
levels of milk restriction experienced as calves. Supplemental water was required in addition to legume hay, however, and underscores the crucial role of watering constraints in this and similar systems. The compensatory effect of supplementation was most apparent at weaning, and there was also a slight carry-over effect in terms of a 2 to 4 month reduction in time to puberty for heifers. Most other production features, however, had completely converged by the time animals reached maturity. This was largely due to compensatory growth of control animals. Despite some of these results, further consideration of the rationale and realworld risks of pastoral production has led us to conclude that supplementation to enhance anything but animal survivorship is a highly risky, and a likely wasteful, use of scarce resources. Lowinput management is therefore justified when production risks are high. All things considered, our work also undermines the notion that moderate levels of milk consumption by pastoralists constitutes a significant loss for the animal production system; in our case this was on the order of 189 to 217 liters of milk per calf. Finally, the future risks of losing benefits of past investments in animal production must be considered and incorporated into stochastic economic analyses of production interventions. Such risks are particularly important in traditional pastoral production systems.

\section{Literature Cited}

Alberro, M. 1986. The Boran cattle and their tribal owners. World Anim. Rev. 57:30-39.

Coppock, D.L. 1994. The Borana Plateau of Southern Ethiopia: Synthesis of pastoral research, development, and change, 198091. Systems Study No. 5. International Livestock Center for Africa, Addis Ababa.

Coppock, D.L. and J.D. Reed. 1992. Cultivated and native browse legumes as calf supplements in Ethiopia. J. Range Manage. 45(3):231-238.

Cossins, N.J. and M. Upton. 1988. Options for improvement of the Borana pastoral system. Agr. Systems 27:251-278.

Dahl, G. and A. Hjort. 1976. Having herds: Pastoral herd growth and household economy. Stockholm Studies in Social Anthropology. Univ. Stockholm.
Day, R.W. and G.P. Quinn. 1989. Comparisons of treatments after an analysis of variance in ecology. Ecol. Monogr. 59(4):433-463.

de Leeuw, P.N. and R.T. Wilson. 1987. Comparative productivity of indigenous cattle under traditional management in sub-Saharan Africa. Quart. J. Int. Agr. 26:377-390.

Dobson, H. and M. Kamonpatana. 1986. A review of female cattle reproduction with special reference to a comparison between buffaloes, cows, and zebus. J. Reprod. Fertil. 77:1-36.

Fitzhugh, H.A. 1976. Analysis of growth curves and strategies for altering their shape. J. Anim. Sci. 42:1036-1051.

Holden, S.J., D.L. Coppock, and Mulugeta A. 1991. Pastoral dairy marketing and household wealth interactions and their implications for calves and humans in Ethiopia. Hum. Ecol. 19(1):35-59.

King, J.M. 1983. Livestock water needs in pastoral Africa in relation to climate and forage. Res. Rep. 7. International Livestock Center for Africa, Addis Ababa.

Laster, D.B., Smith, G.M., Cundiff, L.V., and K.E. Gregory. 1976. Characterization of biological types of cattle. IV. Postweaning growth and puberty of heifers. J. Anim. Sci. 43:500-508.

Macfarlane, J.S. and K. Worrall. 1970. Observations on the occurrence of puberty in Bos indicus heifers. East Afr. Agr. For. J. p. 409-410.

Menwyelet, A. 1990. Ecology of calf pastures and supplementary feeding by Borana pastoralists of southern Ethiopia. Master's thesis, Colorado State Univ., Fort Collins, Colo.

Mukasa-Mugerwa, E. 1989. A review of reproductive performance of female $B o s$ indicus (zebu) cattle. Monogr. 6. International Livestock Center for Africa, Addis Ababa.

Mukasa-Mugerwa, E., Tegegne, A., Mattoni, M., and G. Cecchini. 1989. Effect of oestrous synchronization with prostaglandin F2 alpha in Ethiopian zebu (Bos indicus) cows. Anim. Prod. 48:361-371.

Mulugeta, A. 1990. Borana cattle herds: Productivity, constraints, and possible interventions. Master's thesis, Colorado State Univ., Fort Collins, Colo.

Nelsen, T.C., Short, R.E., Phelps, D.A., and R.B. Staigmiller. 1985. Nonpuberal estrus and mature cow influences on growth and puberty in heifers. J. Anim. Sci. 61:470-473

Nicholson, M.J.N. 1987. The effect of drinking frequency on some aspects of the productivity of zebu cattle. J. Agr. Sci. (Camb.) 108:119-128.
Pratt, D.J. and M.D. Gwynne (ed.). 1977. Rangeland management and ecology in East Africa. Hodder and Stoughton Co., London.

Preston, T.R. 1989. The development of milk production systems in the tropics. Tech. Center for Agr. and Rural Cooperation, Wageningen.

Richardson, F.D., Oliver, J., and G.P.Y. Clarke. 1978. The pre-weaning and postweaning growth of beef calves in relation to the amounts of milk and solid food consumed during the suckling period. Rhodesian J. Agr. Res. 16:97-108.

Rutter, L.M. and R.D. Randel. 1986. Nonpuberal estrus in beef heifers. J. Anim. Sci. 63:1049-1053.

SAS. 1987. SAS/STAT TM Guide for personal computers, 6 ed. Statistical Analysis System Institute, Inc., Cary, N.C.

Tawonezvi, H.P.R. 1989. Growth of Mashona cattle on range in Zimbabwe. I. Environmental influences on liveweight and weight gain. Trop. Anim. Health. Prod. 21:37-42.

Wagenaar, K.T., Diallo, A., and A.R. Sayers. 1986. Productivity of transhumant Fulani cattle in the inner Niger delta of Mali. Res. Rep. 13. International Livestock Center for Africa, Addis Ababa.

Waters-Bayer, A. 1988. Dairying by settled Fulani agropastoralists in central Nigeria: The role of women and implications for dairy development. Farming Systems and Resource Economics in the Tropics, vol. 4. Wissenschafts Verlag. Kiel.

Wilson, R.T. 1987. Livestock production in central Mali: Factors influencing growth and liveweight in agro-pastoral cattle. Trop. Anim. Health. Prod. 19:103-114.

Winer, B.J., D.R. Brown, and K.M. Michels. 1991. Statistical principles in experimental design. $3^{\text {rd }}$ ed. McGraw-Hill, Inc., New York, N.Y. 